\title{
Valorization of Cork Using Subcritical Water
}

\author{
Mónica Cunha *(D), Ana Lourenço, Susana Barreiros, Alexandre Paiva and Pedro Simões * \\ LAQV-REQUIMTE, Chemistry Department, Faculdade de Ciências e Tecnologia, Universidade Nova de Lisboa, \\ 2829-516 Caparica, Portugal; p30@fct.unl.pt (A.L.); sfb@fct.unl.pt (S.B.); abp08838@fct.unl.pt (A.P.) \\ * Correspondence: mp.cunha@campus.fct.unl.pt (M.C.); pcs@fct.unl.pt (P.S.); Fax: +351-212-948-385 (P.S.) \\ Academic Editors: Stela Jokić and Jelena Vladić \\ Received: 10 September 2020; Accepted: 12 October 2020; Published: 14 October 2020

\begin{abstract}
Granulated cork was submitted to subcritical water extraction/hydrolysis in a semicontinuous reactor at temperatures in the range of $120-20{ }^{\circ} \mathrm{C}$ and with a constant pressure of 100 bar. The influence of temperature on the composition of the cork extracts obtained was assessed-namely, their content of carbohydrates and phenolics. The extraction yield increased with the temperature, and this was associated with the decrease in the dielectric constant of water and the increase in its ionic product. Extracts composed of up to $36 \%$ phenolics were obtained at temperatures of up to $120^{\circ} \mathrm{C}$, with an antioxidant activity only two times lower than that of pure gallic acid, but in low amounts. Assays at higher temperatures generated extracts richer in carbohydrates and with a phenolics content of ca. $20 \mathrm{wt} . \%$ in comparatively far higher amounts. Neither the amount of suberin nor its structure were affected by the subcritical water treatment.
\end{abstract}

Keywords: cork; Quercus suber L.; subcritical water; phenolics; carbohydrates; antioxidant activity

\section{Introduction}

Cork is a thick, continuous layer that envelops the stems of certain species of oak trees in Southern Europe and Northern Africa, serving as a protective layer between the tree's living cells and the environment. As a natural and renewable material harvested from the bark of Quercus suber L., cork has considerable economic value [1]. Portugal is the world leader in the cork sector, having exported 201 thousand tons in 2018 (more than $90 \%$ of its production), which represents a share of $62.5 \%$ of the world market [2]. Some the unique characteristics of cork are its low density, low permeability to both gases and liquids, elastic compression and recovery, low thermal and electrical conductivity, acoustic insulation, resistance to abrasion, fire retardant qualities, and hypoallergenic nature. These properties have made cork an attractive material for a wide range of sectors, from building construction to aeronautics. However, about $70 \%$ of all the cork used finds application in the wine industry in the form of cork stoppers [2].

The main by-products of the cork industry are cork granulates that result from the transformation of raw cork into cork stoppers. Cork granulates consist mainly of scraps and parings from the cutting stage, together with the material rejected at the selection stage of natural cork stoppers. Granulates of differing granulometry are first agglutinated, and then subjected to heat and pressure in autoclaves to form expanded agglomerates, if they are agglutinated without the use of any synthetic agents, or to form composite agglomerates if synthetic resins are used [3].

Both the manufacturing of cork stoppers and the formation of cork agglomerates produce waste, essentially rejected material that represents $20-30 \%$ of the industry's raw cork feed [4]. Cork powder or dust, which makes up most of the cork waste, is usually burned to produce energy, while the remaining rejected granulate is reused in the manufacturing process. Though mostly recycled in some form, cork waste remains a by-product of the cork industry with a low commercial value [4,5]. 
Cork consists mostly of suberin (ca. 40\%), lignin (ca. 22\%), carbohydrates (ca. 18\%), extractives (ca. 15\%), and inorganics (ca. 1\%) [6]. There has been growing interest in the extractives present in cork and cork by-products, more specifically in the bioactive compounds, such as polyphenols and triterpenoids (e.g., friedelin), for their anti-inflammatory, anti-cancer, anti-oxidative, anti-viral, anti-fungal, and anti-bacterial properties [7].

The polyphenols found in cork and cork by-products have seen an increase in applications in the food, pharmaceutical, and cosmetics industries [5]. The phenolic compounds from cork and cork by-products are most often obtained through solvent extraction. One common method involves the use of methanol/water mixtures, sometimes followed by extraction with an organic solvent, such as ethyl ether [8]. Another process involves sequential extraction with solvents of increasing polarity (dichloromethane, methanol, and water) to fractionate the cork extracts into separate lipophilic and phenolic fractions [9]. A comparative study that used a variation of both of these methods, with the initial removal of the lipophilic fraction from all samples, reported the generation of extracts with 20 to $35 \mathrm{~g}$ of phenolics/100 $\mathrm{g}$ extract, corresponding to a recovery of about 2.4 to $10.6 \mathrm{mg}$ of phenolics/g cork [10]. Bouras et al. [11] employed microwave-assisted extraction to obtain extracts from Quercus bark using mixtures of three different solvents—-namely, methanol, ethanol, and water-in different proportions. The authors reported a total phenolic content of the extracts ranging from 1.6 to $2.1 \mathrm{~g}$ of phenolics/100 g extract. Recently, a process for extracting phenolic compounds from cork granulates using a water/propylene glycol mixture has been described in a patent application. Seven different phenolic compounds were identified in the hydro-glycolic extracts, corresponding to a recovery of 10 to $16 \mathrm{mg}$ of phenolics/g of cork granulate [12].

Cellulose, hemicellulose, and lignin, the three major lignocellulosic components of the plant cell walls of cork, are also important natural bioresources, not only in producing biofuels, but also in obtaining several value-added chemicals. However, most of the chemical processes used to decompose and extract these components involve the use of acid, alkali, and organic solvents [13]. A green alternative for the processing of biomass is the use of pressurized hot water, or subcritical water (SBW). SBW is liquid water at high temperatures and above its vapor pressure. At these conditions, the dielectric constant of the water decreases and its ionic product increases, making water a more reactive medium for the hydrolysis of lignocellulosic matrices [14].

The present work focuses on obtaining extracts from granulated cork of the Quercus suber L. species, enriched in different value-added compounds, using a semi-continuous, SBW treatment.

\section{Results and Discussion}

\subsection{Chemical Characterization of Granulated Cork}

The water content of the original granulated cork was $5.6 \pm 0.2 \mathrm{~g} / 100 \mathrm{~g}$ of cork. The main component, as shown in Table 1, was suberin, at ca. $41 \mathrm{~g} / 100 \mathrm{~g}$ of dry granulated cork. This is within the range reported by other authors [15-17], although the suberin content has been shown to vary significantly in raw unprocessed cork samples, even those collected from the same tree $[1,15,16]$. After suberin, the more predominant components of cork are lignin and carbohydrates, with suberin:lignin and lignin:carbohydrates ratios falling within the range of values reported in the literature for virgin cork from Quercus suber L. (the main oak species in Portugal) [15]. Cellulose, a homopolysaccharide composed of glucose monomers, accounts for slightly less than half of the total amount of carbohydrates of the granulated cork, the rest being the heteropolysaccharide hemicellulose, made of the sugar monomers, similar to what has been observed by other authors [15]. An HPLC chromatogram of the monosaccharides of the granulated cork is given in Supplementary Figure S5. 
Table 1. Composition of granulated cork on a dry weight basis.

\begin{tabular}{cc}
\hline Component & wt.\% \\
\hline Ashes & $0.89 \pm 0.02$ \\
Extractives & $11.4 \pm 2.2$ \\
n-Hexane & $3.3 \pm 0.4$ \\
Ethanol & $4.4 \pm 0.8$ \\
Water & $3.7 \pm 1.0$ \\
Suberin & $41.0 \pm 3.4$ \\
Lignin & $24.9 \pm 3.4$ \\
Soluble & $1.6 \pm 0.2$ \\
Insoluble & $23.3 \pm 3.2$ \\
Carbohydrates & $18.4 \pm 5.2$ \\
Cellulose ${ }^{1}$ & $7.8 \pm 2.1$ \\
Hemicellulose & $10.6 \pm 3.1$ \\
Protein & $3.2 \pm 0.1$ \\
\hline
\end{tabular}

${ }^{1}$ Measured as glucose.

Granulated cork has a significant content of extractives, up to $11.4 \mathrm{wt} . \%$ of dry matter, although a little lower than virgin cork, with $15.3 \mathrm{wt} . \%$ on average [15]. Non-polar substances such as triglycerides, waxes, and triterpenes, soluble in $n$-hexane, account for approximately a third of the total extractives. Polar compounds, including, among others, polyphenols and soluble sugars, extracted by ethanol and water, make up the rest of the cork extractives. The total phenolic content (TPC) of the combined ethanol and water extracts, measured by the Folin-Ciocalteau colorimetric method, was found to be $3.9 \pm 0.3 \mathrm{~g} \mathrm{GAE} / 100 \mathrm{~g}$ dry cork granulate. A previous study on the phenolic content of raw cork extractives reports values of up to $1.99 \pm 0.01 \mathrm{~g}$ GAE$/ 100 \mathrm{~g}$ dry cork [18]. The total carbohydrates content (TCC) of the combined ethanol and water extracts was found to be $1.41 \pm 0.07 \mathrm{~g}$ GE/100 g dry cork granulate, a relatively low amount when compared to other lignocellulosic biomass matrices [19-21]. Other minor components-namely, ash and protein-fell within the ranges observed in the literature for virgin cork [9].

\subsection{Efficiency of $S B W$ Extraction/Hydrolysis}

The influence of temperature and water flow rate on the yield of the SBW extraction/hydrolysis of granulated cork can be seen in Table 2 .

Table 2. Effect of temperature on the SBW extraction/hydrolysis of granulated cork.

\begin{tabular}{cccc}
\hline Temperature $\left({ }^{\circ} \mathbf{C}\right)$ & $\begin{array}{c}\text { Extraction Yield } \\
(\mathbf{g} / \mathbf{1 0 0} \text { g Cork) }\end{array}$ & $\begin{array}{c}\text { Yield of Carbohydrates } \\
(\mathbf{g} / \mathbf{1 0 0} \text { g Cork })\end{array}$ & $\begin{array}{c}\text { Yield of Phenolics } \\
(\mathrm{g} / \mathbf{1 0 0} \text { g Cork })\end{array}$ \\
\hline 120 & $2.17 \pm 0.07$ & $0.59 \pm 0.02$ & $0.73 \pm 0.04$ \\
150 & $10.5 \pm 0.3$ & $2.86 \pm 0.16$ & $2.15 \pm 0.10$ \\
200 & $17.0 \pm 0.5$ & $7.27 \pm 0.06$ & $3.76 \pm 0.18$ \\
\hline
\end{tabular}

Temperature had a strong effect on all the parameters monitored. This can be attributed to the increase in the ionic product of water with increasing temperature. In the temperature range $150-200{ }^{\circ} \mathrm{C}$, the ionic product of water is about three orders of magnitude higher than at room temperature (an increase from $\mathrm{p} \mathrm{K}_{\mathrm{w}}=14$ to ca. 11 [22]), thus promoting the hydrolysis of biomass components-namely, structural carbohydrates. In addition, temperature affects the kinetics of the hydrolysis reaction itself. Increasing the temperature increases the thermal energy, thereby increasing the reaction rates of hydrolysis [23].

The highest recovery of carbohydrates occurred at $200{ }^{\circ} \mathrm{C}$, with an overall yield of $7.27 \mathrm{~g}$ of carbohydrates/100 g of granulated cork, which corresponds to roughly $40 \%$ of the total content of carbohydrates available in granulated cork. At $120^{\circ} \mathrm{C}$, SBW should only be able to access soluble 
sugars. At $150{ }^{\circ} \mathrm{C}$, the results in Table 2 suggest that SBW was able to remove a fraction of hemicellulose. At $200{ }^{\circ} \mathrm{C}$, the results suggest that ca. $70 \%$ of the hemicellulose was removed as well by SBW, with the resilience of cellulose preventing its depolymerization by SBW at that temperature.

The extraction yield of phenolics followed a similar pattern: the higher the temperature reached in the assay, the higher the yield of phenolics obtained, reaching $3.76 \mathrm{~g} / 100 \mathrm{~g}$ granulated cork at $200{ }^{\circ} \mathrm{C}$. This amount corresponds to ca. $96 \%$ of the total content of phenolics available in the original raw cork. The dielectric constant of water decreases sharply with increasing temperature, varying from 78.5 at $25^{\circ} \mathrm{C}$ to ca. 35 at $200{ }^{\circ} \mathrm{C}$, a value that is comparable to the dielectric constant of methanol at room temperature and pressure [24]. At such conditions, subcritical water gains the ability to dissolve less polar compounds.

Table 2 gives the overall yields. As indicated in the section on semi-continuous SBW extraction, the liquors produced in each assay were divided into separate samples. Each sample corresponded to all the liquor collected for a given temperature interval, as the water outlet temperature rose from ambient to $50{ }^{\circ} \mathrm{C}$, from $50{ }^{\circ} \mathrm{C}$ to a higher temperature, and so forth. The analysis of each of these samples enables a more detailed analysis of the effect of temperature on the SBW treatment, as shown in Table 3.

Table 3. Cumulative extraction yields of the SBW assays with granulated cork.

\begin{tabular}{|c|c|c|c|c|}
\hline $\begin{array}{c}\text { Target } \\
\text { Temperature }\left({ }^{\circ} \mathrm{C}\right)\end{array}$ & $\begin{array}{c}\text { Temperature of Sample } \\
\text { Collection }\left({ }^{\circ} \mathrm{C}\right)\end{array}$ & $\begin{array}{l}\text { Extraction Yield } \\
\text { (g/100 g Cork) }\end{array}$ & $\begin{array}{l}\text { Yield of Carbohydrates } \\
\text { (g/100 g Cork) }\end{array}$ & $\begin{array}{l}\text { Yield of Phenolics } \\
\text { (g/100 g Cork) }\end{array}$ \\
\hline \multirow{3}{*}{$120^{\circ} \mathrm{C}$} & $<50$ & 0.3 & 0.07 & 0.07 \\
\hline & $50-120$ & 1.6 & 0.44 & 0.54 \\
\hline & 120 & 2.2 & 0.59 & 0.73 \\
\hline \multirow{3}{*}{$150^{\circ} \mathrm{C}$} & $<50$ & 0.7 & 0.09 & 0.17 \\
\hline & 50-150 & 7.3 & 1.43 & 1.61 \\
\hline & 150 & 10.5 & 2.86 & 2.15 \\
\hline \multirow{4}{*}{$200^{\circ} \mathrm{C}$} & $<50$ & 0.3 & 0.09 & 0.08 \\
\hline & 50-120 & 1.2 & 0.25 & 0.31 \\
\hline & $120-200$ & 12.8 & 6.49 & 2.81 \\
\hline & 200 & 17.0 & 7.27 & 3.76 \\
\hline
\end{tabular}

While the highest recovery of phenolics was achieved in the $200{ }^{\circ} \mathrm{C}$ assay, the extract with the highest phenolic content was obtained in the assay targeting $120^{\circ} \mathrm{C}$ as temperature increased from 50 to $120^{\circ} \mathrm{C}$. In fact, $1.3 \mathrm{~g}$ of this extract had $0.47 \mathrm{~g}$ of phenolics, which corresponds to ca. $36 \mathrm{wt} . \%$. However, the amount of extract obtained at such conditions is very small. In the assay targeting $200{ }^{\circ} \mathrm{C}$, for instance, as temperature increased from 120 to $200^{\circ} \mathrm{C}, 11.6 \mathrm{~g}$ of extract was produced with a TPC of ca. 22 wt. \%, while, when the temperature was kept constant at $200{ }^{\circ} \mathrm{C}, 4.2 \mathrm{~g}$ of extract was produced, with a TPC of ca. $22.6 \mathrm{wt} . \%$.

The results of the HPLC analysis of the phenolic compounds in the SBW extracts are shown in Table 4 for the assay targeting $200^{\circ} \mathrm{C}$. HPLC chromatograms are shown in Supplementary Figures S1-S4. Gallic acid was found to be the phenolic compound present in the highest concentration. Caffeic acid and ferulic acid were present in relatively lower amounts. Ellagic acid was only found in the extracts obtained at temperatures higher than $120^{\circ} \mathrm{C}$. This phenolic acid is known to have antioxidant and other beneficial properties, although it shows a poor water solubility and low bioavailability. It is understood that its planar and symmetrical structure, associated with irreversible bindings to cellular DNA and proteins, is the cause of the very poor bioavailability of ellagic acid [25]. It is possible that SBW is only able to extract ellagic acid at higher temperatures, since at such conditions the ionic product of water makes it a more reactive medium for hydrolysis. Furthermore, at $200{ }^{\circ} \mathrm{C}$ the dielectric constant of water is similar to that of methanol at room temperature, as mentioned earlier (ellagic acid is fairly soluble in methanol). 
Table 4. Phenolic compounds in the SBW extracts obtained in the assay targeting $200{ }^{\circ} \mathrm{C}$.

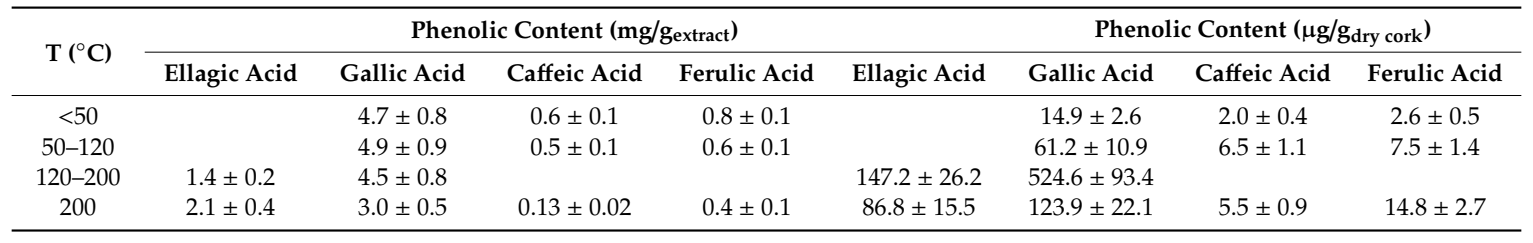

The values obtained in this work agree with those reported in the literature, considering the natural variability of cork composition with the collection year and site, as well as the type of raw material used. Mislata et al. [26] obtained ethyl acetate extracts from granulated corks macerated in a hydroalcoholic solution. They identified gallic acid as the phenolic species with highest concentration in the extracts, with values of between 60.6 and $180.9 \mu \mathrm{g} / \mathrm{g}_{\text {extract, }}$, followed by protocatechuic acid, varying between 41.3 and $161.6 \mu \mathrm{g} / \mathrm{g}_{\text {extract }}$. Batista et al. [12] obtained a water/propylene glycol extract from granulated cork. The gallic acid and protocatechuic acid contents of their extracts, $60-100 \mu \mathrm{g} / \mathrm{g}$ cork and 100-130 $\mathrm{\mu g} / \mathrm{g}$ cork, respectively, are within the range of our values. On the other hand, ellagic acid (6800-8200 $\mu \mathrm{g} / \mathrm{g}$ cork) and castalagin (1800-2100 $\mu \mathrm{g} / \mathrm{g}$ cork) were identified in higher concentrations than our SBW extracts. The same was reported by Santos et al. [10] for a methanol extract obtained from cork powder. The major phenolic compounds identified were ellagic acid, followed by gallic, protocatechuic, and caffeic acids and esculetin.

\subsection{Antioxidant Activity}

The antioxidant activity of each of the samples collected at various temperature ranges, expressed here as the half maximal effective concentration, or $\mathrm{EC}_{50}$, is shown in Table 5.

Table 5. Phenolic compounds in the SBW extracts obtained in the assay targeting $200{ }^{\circ} \mathrm{C}$.

\begin{tabular}{ccc}
\hline Temperature $\left({ }^{\circ} \mathbf{C}\right)$ & EC $_{\mathbf{5 0}}$ ( $\mathbf{m g}$ extract $/ \mathbf{m g}$ DPPH $)$ & TPC $(\mathrm{g} / \mathbf{1 0 0}$ g extract $)$ \\
\hline$<50$ & $0.406 \pm 0.007$ & $26.7 \pm 2.1$ \\
$50-120$ & $0.253 \pm 0.001$ & $25.6 \pm 0.2$ \\
$120-200$ & $0.459 \pm 0.006$ & $21.6 \pm 1.3$ \\
200 & $0.510 \pm 0.004$ & $22.6 \pm 0.4$ \\
\hline
\end{tabular}

For comparison, pure gallic acid analyzed under the same conditions showed an $\mathrm{EC}_{50}$ of $0.035 \pm 0.001 \mathrm{mg} / \mathrm{mg}$ DPPH.

The lowest value of $\mathrm{EC}_{50}$ obtained-at $0.25 \mathrm{mg}$ extract/mg DPPH—and therefore the highest antioxidant activity was obtained for the extract collected in the temperature range between $50{ }^{\circ} \mathrm{C}$ and $120^{\circ} \mathrm{C}$. This range of temperatures generally corresponded to the higher TPC in all the assays performed. Taking the TPC of the $50-120^{\circ} \mathrm{C}$ extract into account, the earlier value would correspond to an $\mathrm{EC}_{50}$ of ca. $0.07 \mathrm{mg}$ phenolics $/ \mathrm{mg} \mathrm{DPPH}$, only two times higher than the $\mathrm{EC}_{50}$ of the gallic acid standard. At higher temperatures, the slight decrease in the TPC of the extracts was accompanied by a decrease in the antioxidant activity, with the $\mathrm{EC}_{50}$ varying from 0.46 to $0.51 \mathrm{mg}$ extract $/ \mathrm{mg} \mathrm{DPPH}$ in the $120^{\circ} \mathrm{C}$ to $200^{\circ} \mathrm{C}$ temperature range. Increasing the temperature led to higher concentration of carbohydrates in the extracts, and this may explain the decrease in the antioxidant activity, if compared with the samples obtained at lower temperatures. Furthermore, ellagic acid was only found in the latter extracts. The $\mathrm{EC}_{50}$ of pure ellagic acid under the same conditions of analysis led to a value of $0.047 \pm 0.001 \mathrm{mg} / \mathrm{mg} \mathrm{DPPH}$, which is slightly higher than that for pure gallic acid. This may also partly explain the decrease observed in the antioxidant activity of the $120-200{ }^{\circ} \mathrm{C}$ extracts when compared with the others.

Even so, the $\mathrm{EC}_{50}$ values obtained for cork extracts are similar or even better than those obtained previously for extracts from white wine grape pomace (0.53 to $1.8 \mathrm{mg}$ extract $/ \mathrm{mg}$ DPPH) [19] and spent coffee grounds (0.6 to $3 \mathrm{mg}$ extract/mg DPPH) [27]. For comparison, a water infusion of as-received 
granulated cork at normal boiling temperature was carried out for one hour, using a volume of solvent to cork mass of ca. $190 \mathrm{~mL} / \mathrm{g}$. The extraction yield obtained was $2.4 \mathrm{~g} / 100 \mathrm{~g}$ cork. The extract had a TPC of $55 \mathrm{~g} / 100 \mathrm{~g}$ of extract and an $\mathrm{EC}_{50}$ of $0.37 \mathrm{mg}$ extract/mg DPPH. Although this extract had a higher phenolic content than the SBW extracts, its antioxidant activity was lower, possibly explained by other extractives solubilized by "normal" hot water.

The $\mathrm{EC}_{50}$ values obtained for the SBW extracts of granulated cork compare well with those reported in the literature for cork extracts. Aroso et al. [28] extracted cork powder with different solvents, water, ethanol, and respective mixtures, and the respective $\mathrm{EC}_{50}$ values ranged from 7.9 to $13 \mu \mathrm{g}$ extract $/ \mathrm{mL}$ (for comparison, our results varied between 10 to $19 \mu \mathrm{g}$ extract $/ \mathrm{mL}$ ). Santos et al. [10] reported an $\mathrm{EC}_{50}$ of 3.6 to $5.8 \mu \mathrm{g} / \mathrm{mL}$ for the methanol/water extracts from cork powder.

The SBW extracts of granulated cork exhibited a high antioxidant activity, showing potential for applications in the cosmetics, food, and pharmaceutical industries.

\subsection{Suberin and Lignin Extraction}

Due to the low amounts of solid extract collected in each SBW extraction run (less than $2 \mathrm{~g}$ of extract in total), the suberin and lignin extraction yield was determined indirectly through the difference between their content in the original cork and in the residue of the SBW assay at $200{ }^{\circ} \mathrm{C}$.

The SBW residue showed a lignin and carbohydrate content of $17.8 \mathrm{~g} / 100 \mathrm{~g}$ dry cork and $12.0 \mathrm{~g} / 100 \mathrm{~g}$ dry cork, respectively. Compared with the respective content in the original granulated cork, it is possible to conclude that the subcritical water extracted ca. $29 \%$ of the lignin initially present in the cork, and ca. $35 \%$ of the total amount of carbohydrates in the granulated cork. The latter is relatively close to the total amount of carbohydrates quantified in the SBW extracts.

The quantification of suberin content in both the original granulated cork and the residue of the SBW extraction assay at $200{ }^{\circ} \mathrm{C}$ gave similar values within the experimental error. This may indicate that subcritical water at the range of temperatures studied in this work did not significantly hydrolyze the cork suberin. Nevertheless, the suberin monomers present in both the original cork and the SBW residue were analyzed through FTIR and NMR spectroscopy to assess if the SBW was still able to alter the structure of suberin during the assay.

The FTIR spectrum and the solid-state ${ }^{1} \mathrm{H}-\mathrm{NMR}$ spectrum of the isolated suberin monomers of the original granulated cork and of the SBW cork residue are shown in Figures 1 and 2.
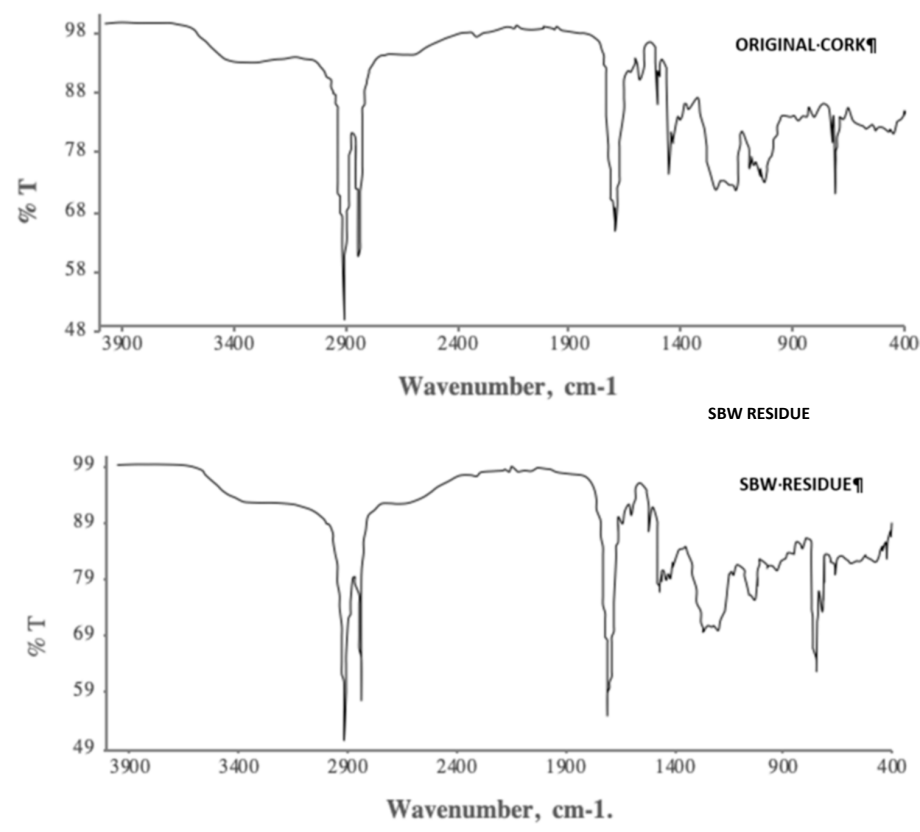

Figure 1. FTIR spectrum of the isolated suberin monomers from granulated cork, before and after the SBW treatment. 


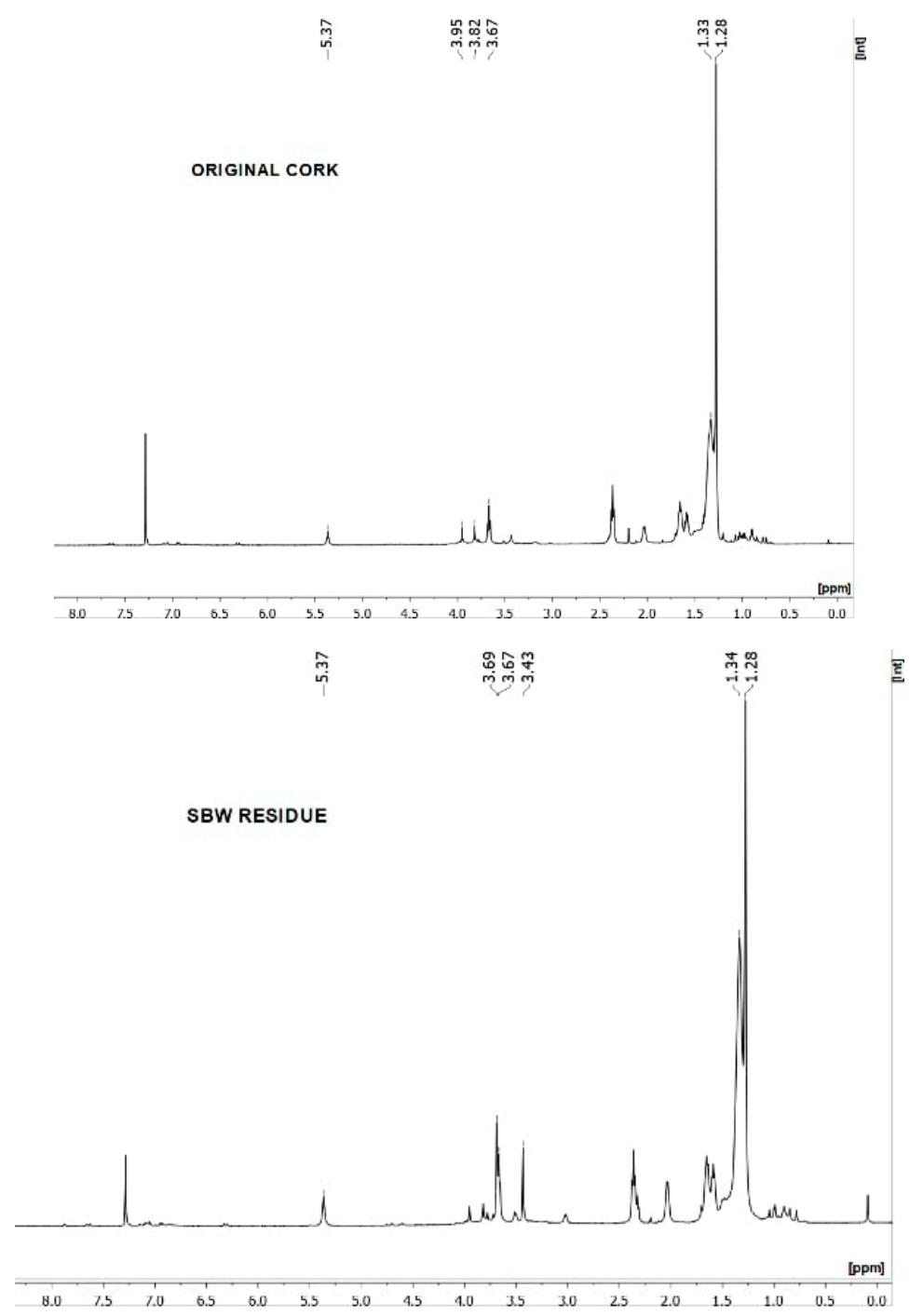

Figure 2. ${ }^{1} \mathrm{H}$ NMR spectra of the suberin monomers of granulated cork, before and after the SBW treatment, in deuterated chloroform $\left(\mathrm{CDCl}_{3}\right)$.

The FTIR spectrum of our granulated cork is comparable to the one shown for an extractives-free pure cork sample [1]. The broad band with a maximum at $3300 \mathrm{~cm}^{-1}$ can be attributed to hydrogenbonded $\mathrm{O}-\mathrm{H}$ groups (intermolecular). The aliphatic nature of the suberin structure is characterized by strong absorptions at 2912, 2849, and $1473 \mathrm{~cm}^{-1}$ (methylene, $-\mathrm{CH}_{2}-$ ). Strong bands at $1707 \mathrm{~cm}^{-1}$ (carbonyl, $\mathrm{C}=\mathrm{O}$ ) and $1257 \mathrm{~cm}^{-1}$ (alkyl-aryl ethers, $=\mathrm{C}-\mathrm{O}-\mathrm{C}$ ) also indicate the prevalence of the ester moieties that typically characterize the ester linkages in the suberin structure. The band at $1600 \mathrm{~cm}^{-1}$ can be attributed to $\mathrm{C}=\mathrm{C}$ double bonds [29].

In the ${ }^{1} \mathrm{H}-\mathrm{NMR}$ spectrum, the signal at $\delta 5.3 \mathrm{ppm}$ corresponds to alkenyl protons $\left(\mathrm{CH}_{2}=\mathrm{CH}-\right)$. The signals in the region between $\delta 3.9$ and $\delta 3.4 \mathrm{ppm}$ can be attributed to methylene protons vicinal to oxygen atoms of the ester functions and to the methyne of the glycerol moiety. The signal at $\delta 3.4 \mathrm{ppm}$ was assigned to the methoxy groups $\left(-\mathrm{O}-\mathrm{CH}_{3}\right)$ that resulted from the methanolysis. Signals that could be attributed to the aromatic moieties in the suberin structure are negligible or entirely absent in this spectrum. The alkaline methanolysis method used in this study favors the removal of the aliphatic chains that make up the majority of suberin's aliphatic domain, which might explain not only these negligible aromatic signals but also the predominance of the signals in the aliphatic regions $(\delta 1.3$ and $\delta 1.2 \mathrm{ppm}$ ) of both spectra. The same can be said about the absence of peaks assigned to carboxyl moieties (-COOH) [29]. 
Comparing the FTIR and ${ }^{1} \mathrm{H}-\mathrm{NMR}$ spectra of the original granulated cork and the SBW residue, one cannot observe significant differences between them, thus indicating that the structure of suberin was not altered during the SBW hydrolysis of granulated cork.

\section{Materials and Methods}

\subsection{Materials}

The granulated cork (0.5-1 mm particle size) kindly provided by a Corticeira Amorim (Mozelos, Portugal), was stored in plastic bags at room temperature.

All the reagents used in this work were of high grade. Chloroform (99\%) was from Carlo Erba Reagents (Barcelona, Spain), methanol (99\%) phenol, and sulfuric acid (96\%) were from Sigma-Aldrich Co. (St. Louis, MO, USA), and ellagic acid, gallic acid, caffeic acid, and ferulic acid were from Merck KGaA (Darmstadt, Germany).

\subsection{Chemical Characterization of Granulated Cork}

The water content of granulated cork was measured in a thermogravimetric balance (Kern DAB 100-3) at $105^{\circ} \mathrm{C}$.

The ash content was determined gravimetrically, through weight difference, after placing a porcelain crucible containing ca. $0.3 \mathrm{~g}$ of sample in a muffle at $550{ }^{\circ} \mathrm{C}$ for $6 \mathrm{~h}$ and then in a desiccator to cool down.

The protein content was determined indirectly by the measuring nitrogen content through elementary microanalysis, using a nitrogen-to-protein conversion factor of 6.25 [30].

A series of extractions were performed with solvents of increasing polarity to remove all the extractives in a sequence of three steps [1]. The first step was a Soxhlet extraction with $70 \mathrm{~mL}$ of $n$-hexane (at $69^{\circ} \mathrm{C}$ ) for $3 \mathrm{~h}$ to remove non-polar compounds, mostly triterpenes, long chain alkanes, and alkanols. The second step was a Soxhlet extraction with $70 \mathrm{~mL}$ of ethanol (at $78{ }^{\circ} \mathrm{C}$ ) for $3 \mathrm{~h}$, and the third step consisted of an infusion using $100 \mathrm{~mL}$ of water, previously heated to normal boiling temperature, for $1 \mathrm{~h}$. Ethanol and water were used to remove polar compounds, mostly phenolics, such as tannins and flavonoids, as well as soluble carbohydrates, which make up the remaining cork extractives [1,9]. Each extract was filtered, the solvent evaporated, and the remaining solid weighed to quantify extractives. The final residue was dried overnight at $45^{\circ} \mathrm{C}$ to remove the remaining solvent before weighing.

The total phenolic content and the soluble carbohydrate content of the ethanol Soxhlet extracts and the extracts obtained by infusion in water were determined by the Folin-Ciocalteu and the phenol-sulfuric acid method, respectively, as described in a further section.

The extractives-free granulated cork was submitted to an alkaline methanolysis reaction to extract and isolate suberin $[9,29,31]$. The complete depolymerization of suberin was achieved by treating, overnight, $150 \mathrm{mg}$ of the sample with $30 \mathrm{~mL}$ of a refluxing mixture of a freshly prepared, dry, $1.0 \mathrm{M}$ solution of sodium methoxide ( $\mathrm{NaOMe})$, a common reagent used to induce the ester cleavage of the suberin structure. The reaction mixture was then filtered. The solid obtained was washed with methanol until a clear liquid was obtained. This liquid was added to the supernatant, yielding a solution that was neutralized to $\mathrm{pH}$ of $5-6$ by adding small quantities of a $2.0 \mathrm{M}$ solution of sulfuric acid in methanol. The solvent was evaporated and the residue was suspended in $75 \mathrm{~mL}$ of water. The suberin monomers in this solid were isolated by extraction with $2 \times 75 \mathrm{~mL}$ of chloroform. The solution obtained was dried with anhydrous sulphate, filtered, evaporated to dryness, and dried under a vacuum, yielding a paste-like material composed of fatty aliphatic monomers of suberin that were quantified by weighing.

Suberin monomer analysis was carried out by Attenuated Total Reflection Fourier Transform Infrared (FT-IR) spectroscopy, using a Perkin Elmer Spectrum 1000 spectrophotometer (PerkinElmer, Waltham, MA, USA), and by ${ }^{1} \mathrm{H}-\mathrm{NMR}$ (Nuclear Magnetic Resonance) spectroscopy, using a Bruker 
AVANCE III 400 apparatus (Bruker, Billerica, MA, USA), after dissolving the suberin monomers in deuterated chloroform.

The solid obtained after the sodium methoxide treatment—suberin-free material—was further washed with water, dried in an oven at $45{ }^{\circ} \mathrm{C}$, and stored for further analysis. The insoluble structural carbohydrates in extractives-free and suberin-free material were quantified through a two-step concentrated acid hydrolysis. To that end, the suberin-free sample was treated with a $72 \%(w / w)$ sulfuric acid solution in a $30^{\circ} \mathrm{C}$ water bath for $1 \mathrm{~h}$, after which the mixture was diluted with $84 \mathrm{~mL}$ of water to a $4 \%(w / w)$ concentration, before being incubated in a silicone bath at $121{ }^{\circ} \mathrm{C}$ for $1 \mathrm{~h}$. The resulting mixture was filtered and the monosaccharide content of the supernatant was determined by HPLC analysis, as described in a further section. The acid soluble lignin (ASL) of the supernatant was determined through the direct reading of its absorbance in the UV spectrum (GE Healthcare, Chicago, IL, USA), at $205 \mathrm{~nm}$. First, the supernatant was diluted with water until its absorbance fell between 0.7 and 1.0. The ASL was calculated using the following equation:

$$
\% A S L=\frac{U V_{a b s} \times \text { Volume }_{\text {filtrate }} \times D F}{\varepsilon x O D W_{\text {sample }} \times \text { Pathlength }} \times 100 .
$$

The residue from the acid hydrolysis was washed, dried, and weighed, and the acid insoluble (Klason) lignin content was calculated after taking into account the protein and acid insoluble ash from the weight of this dry residue [32].

The suberin content of the residue that remained in the reactor after the SBW extraction was determined using the protocol applied for the original cork granulate.

\subsection{Semi-Continuous SBW Extraction}

The extraction of granulated cork was performed in an SBW unit shown schematically in Figure 3. In each experiment, distilled water was pumped using a high-pressure pump (KNAUER Preparative Pump model 1800) (Knauer, Berlin, Germany). The water filled the reactor, a $51 \mathrm{~cm}$-long and $2.6 \mathrm{~cm}$-internal-diameter-wide stainless steel tube, which was previously loaded with ca. $10 \mathrm{~g}$ of granulated cork as received, and placed inside an electric oven with temperature control (Nabertherm model 30-3000 ${ }^{\circ} \mathrm{C}$ N641) (Nabertherm GmbH, Lilienthal, Germany); the pressure was allowed to reach 100 bar, as controlled by a back-pressure regulator valve (Tescom model 26-1700) (Tescom Europe $\mathrm{GmbH} \& \mathrm{Co}$. KG, Selmsdorf, Germany). To prevent the thermal degradation of the raw material, it is only at this point that both the heating cord around the inlet water piping, connected to a temperature controller, and the heating program of the oven where the reactor is placed were activated. This marked the start of the process $(t=0)$, and from this moment onward the liquor leaving the reactor was continuously collected for analysis. The outlet water stream passed through a $15 \mu \mathrm{m}$ filter before being depressurized, cooled down in an ice bath, and collected for analysis. The pressure and temperature of both the inlet and outlet streams were monitored throughout the experiments. The pressure was kept at 100 bar throughout all the experiments to ensure that the water was always a liquid. The SBW water flowrate was fixed at $10 \mathrm{~mL} / \mathrm{min}$ for all the assays. The target temperatures were 120,150 , and $200{ }^{\circ} \mathrm{C}$.

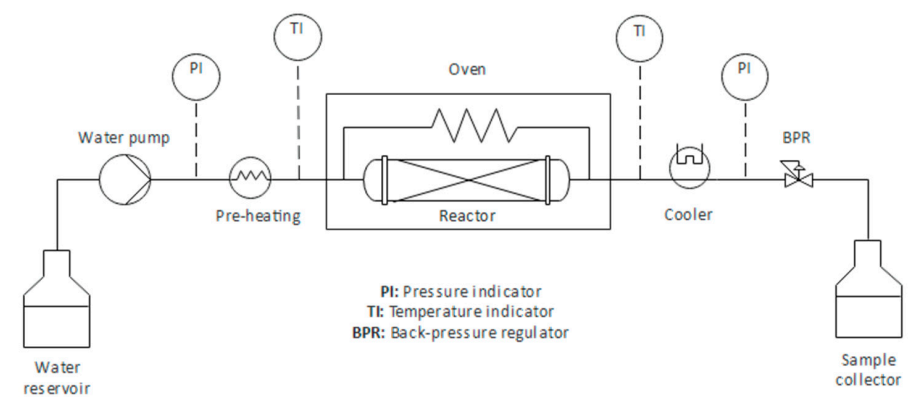

Figure 3. SBW semi-continuous unit for the extraction/hydrolysis of granulated cork. 
The influence of temperature on the SBW extraction was determined by separating into different sampling tubes the amount of liquor collected. For example, in the case of the $200{ }^{\circ} \mathrm{C}$ assay, sample 1 was collected from the $\mathrm{t}=0$ to the time at which the temperature of the outlet stream reached $50{ }^{\circ} \mathrm{C}$. Sample 2 was collected between an outlet temperature of 50 and $120^{\circ} \mathrm{C}$. Sample 3 was collected between 120 and $200{ }^{\circ} \mathrm{C}$. Lastly, sample 4 was collected at an outlet temperature of $200^{\circ} \mathrm{C}$ for a duration of $30 \mathrm{~min}$.

The extraction yield was calculated by measuring the total amount of liquor collected in each sample, determining the amount of extract obtained by lyophilizing a given volume of liquor from that sample, correcting for the total volume of the sample, and finally summing up for all four samples [27].

At the end of the extraction, the heating was turned off and the system was allowed to cool down. Known amounts of each of the liquors collected were stored at $4{ }^{\circ} \mathrm{C}$, to be used for the subsequent quantification of the phenolic and carbohydrate content. The residue that remained in the reactor after the SBW extraction was washed with water and dried in an oven at $100{ }^{\circ} \mathrm{C}$ overnight.

\subsection{Phenolic Analysis}

The total phenolic content (TPC) of the SBW liquors, as well as the ethanol Soxhlet and the water infusion extracts, was determined through the Folin-Ciocalteau colorimetric method [33]. To that end, a gallic acid solution was used to build a calibration curve. Due to the possible interference of protein with phenolics quantification, a step of protein precipitation was performed [34]. This consisted of adding $120 \mu \mathrm{L}$ of $100 \%(w / v)$ trichloroacetic acid to $800 \mu \mathrm{L}$ of sample. The mixture was stirred and stored at $-20{ }^{\circ} \mathrm{C}$ for $5 \mathrm{~min}$, then at $4{ }^{\circ} \mathrm{C}$ for $15 \mathrm{~min}$, after which it was centrifuged $(12,000 \times g$, $15 \mathrm{~min}$ ) and the protein precipitate was discarded. To $20 \mu \mathrm{L}$ of both the recovered supernatant and the standard gallic solutions were added $1.58 \mathrm{~mL}$ of distilled water and $100 \mathrm{~mL}$ of Folin-Ciocalteu reagent. The mixtures were stirred and incubated at room temperature for about $5 \mathrm{~min}$, after which $300 \mu \mathrm{L}$ of sodium carbonate solution were added, followed by incubation in a dry bath at $40{ }^{\circ} \mathrm{C}$ for $30 \mathrm{~min}$. The absorbance was measured at $750 \mathrm{~nm}$, and the calibration curve was used to calculate the TPC, expressed here as grams of gallic acid equivalents per liter $\left(\mathrm{g}_{\mathrm{GAE}} / \mathrm{L}\right)$.

The individual phenolic compounds of SBW granulated cork extracts were identified through HPLC analysis. The analysis, which was performed using a method adapted from the literature [35], was performed with an Agilent Infinity 1100 system, using an injection volume of $20 \mu \mathrm{L}$ and a flow rate of $0.3 \mathrm{~mL} / \mathrm{min}$. The column (Waters NOVAPAC C18 $150 \times 3.9 \mathrm{~mm}, 4 \mu \mathrm{m}$ pore size) (Waters Corporation, Milford, MA, USA) was kept at a constant temperature of $25^{\circ} \mathrm{C}$. The absorbance was measured at $280 \mathrm{~nm}$ using a diode array detector. The mobile phase was a mixture of solvents, (A) water/acetic acid $(99: 1 ; v / v)$ and (B) water/acetonitrile/acetic acid $(79: 20: 1 ; v / v / v)$, with the gradient $80-20 \%$ A for $55 \mathrm{~min}, 20-10 \%$ A from 55 to $70 \mathrm{~min}$, and 10-0\% A from 70 to $90 \mathrm{~min}$. The chromatographic column was washed with $100 \%$ B for 10 min and then stabilized at the initial conditions for another $10 \mathrm{~min}$.

The standards of gallic acid, caffeic acid, ferulic acid, and ellagic acid were prepared and analyzed for identification purposes.

\subsection{Carbohydrate Analysis}

The amount of sugars was determined through HPLC analysis, with a method adapted from the literature [36]. The analysis was performed using a Dionex ICS-3000 system, with electrochemical detection, using a $4 \times 50 \mathrm{~mm}$ Thermo BioLC Dionex AminoTrap precolumn and a $4 \times 250 \mathrm{~mm}$ Thermo Dionex CarboPac SA10 column, with an injection volume of $10 \mu \mathrm{L}$ and a constant temperature of $25^{\circ} \mathrm{C}$. A $1 \mathrm{mM} \mathrm{NaOH}$ solution was used as a mobile phase, at a constant flow rate of $1 \mathrm{~mL} / \mathrm{min}$. Calibration curves were built for the monosaccharides (concentrations between 5-100 mg/L).

The total carbohydrate content (TCC) in the SBW liquors was measured through the phenol-sulfuric acid method. For this method, $\mathrm{D}(+)$-glucose monohydrate solutions were used to build a calibration curve. To $500 \mu \mathrm{L}$ of sample were added $1.5 \mathrm{~mL}$ of sulfuric acid $(96 \%)$ and $300 \mu \mathrm{L}$ of a $5 \%$ phenol aqueous solution. The mixtures were stirred and incubated at $90{ }^{\circ} \mathrm{C}$ in a dry bath for $5 \mathrm{~min}$, after which the 
mixtures were stirred once more and cooled down to room temperature in a water bath. Absorbance was measured at $490 \mathrm{~nm}$, and the calibration curve used to calculate the TCC (expressed here as g/L glucose equivalent -GE).

The methods referred above were also used to analyze the solutions obtained during biomass characterization.

\subsection{Antioxidant Activity}

The antioxidant activity of each SBW extract, as well as the ethanol Soxhlet and water infusion extracts, was determined through the 2,2-diphenyl-1-picrylhydrazyl (DPPH) assay [37].

To that end, a stock solution of $24 \mathrm{mg}$ of DPPH in $100 \mathrm{~mL}$ of methanol was prepared and stored at $-20{ }^{\circ} \mathrm{C}$ for at least $2 \mathrm{~h}$. A small amount of this solution was then diluted by adding methanol, until its absorbance (measured at $517 \mathrm{~nm}$ ) reached near 1 . In each DPPH assay, to $4 \mathrm{~mL}$ of this final adjusted solution were added $150 \mu \mathrm{L}$ of solutions of extract in (50:50, v/v) $\mathrm{H}_{2} \mathrm{O}: \mathrm{EtOH}$ (range of concentrations between 50 and $2000 \mathrm{mg} / \mathrm{L}$ ) or $150 \mu \mathrm{L}$ of only $\mathrm{H}_{2} \mathrm{O}: \mathrm{EtOH}$, with no extract, in the case of the blank.

The mixtures were stirred and stored in the dark for $40 \mathrm{~min}$ at room temperature, after which their absorbance was measured (at $517 \mathrm{~nm}$ ). To determine the samples' antioxidant activity, the scavenging of the free radical was first calculated using the following equation:

$$
\% \text { Inhibition }=\frac{A_{D P P H}-A_{\text {sample }}}{A_{D P P H}}
$$

where $A_{D P P H}$ is the absorbance of the blank and $A_{\text {sample }}$ is the absorbance of the sample with the extract. The antioxidant activity of the extracts is then measured through the half maximum effective concentration $\left(\mathrm{EC}_{50}\right)$, which is calculated from the inhibition curves obtained [19].

\section{Conclusions}

Granulated cork was submitted to subcritical water extraction/hydrolysis in a semi-continuous reactor at different conditions of temperature, with the goal of obtaining extracts enriched in different value-added compounds. Carbohydrates-rich extracts were obtained at temperatures in the $120-200{ }^{\circ} \mathrm{C}$ range. Ca. $70 \%$ of the cork hemicellulose was extracted, with cellulose remaining in the original material. SBW extracted ca. $96 \%$ of the total content of phenolics available in the granulated cork. Phenolics-rich extracts, with a content of up to $36 \mathrm{~g}$ of phenolics/100 $\mathrm{g}$ of extract, were obtained at the lower temperature range of $50-120^{\circ} \mathrm{C}$. All the SBW extracts exhibited a high antioxidant activity, with that of the extract collected between 50 and $120^{\circ} \mathrm{C}$ being only two times lower than the antioxidant activity of gallic acid, showing potential for applications in the cosmetics, food, and pharmaceuticals industries. On the other hand, suberin was not extracted by SBW, and its structure remained intact in the granulated cork, which can thus be used like the original material in many sectors.

Supplementary Materials: The following are available online: HPLC chromatograms of phenolics of SBW extracts in Figures S1-S4, and HPLC chromatogram of monosaccharides of the granulated cork in Figure S5.

Author Contributions: Conceptualization, P.S., A.P., and S.B.; methodology, M.C.; validation, A.P., A.L., and P.S.; formal analysis, M.C.; investigation, M.C.; data curation, M.C.; writing-original draft preparation, M.C. and P.S.; writing-review and editing, S.B.; visualization, M.C.; supervision, A.P. and P.S. All authors have read and agreed to the published version of the manuscript.

Funding: This research was funded by the Associate Laboratory for Green Chemistry-LAQV, which is financed by national funds from FCT/MCTES (UIDB/QUI/50006/2020). MC was funded by Fundação para a Ciência e a Tecnologia, through PhD grant PD/BD/142863/2018, and AP was funded by Fundação para a Ciência e a Tecnologia through project IF/01146/2015.

Acknowledgments: We acknowledge the help of Nuno Costa and Carla Rodrigues from Laboratório de Análises (LAQV, REQUIMTE).

Conflicts of Interest: The authors declare no conflict of interest. 


\section{References}

1. Pereira, H. Cork products and uses. In Cork: Biology Production and Uses; Pereira, H., Ed.; Elsevier: Amsterdam, The Netherlands, 2007; Volume 11, pp. 243-261. [CrossRef]

2. Cork Year Book 19/20. Available online: https://www.apcor.pt/portfolio-posts/boletim-estatistico-1920 (accessed on 7 July 2020).

3. Mestre, A.; Gil, L. Cork for sustainable product design. Cienc. Tecnol. Mater. 2011, 23, 52-63.

4. Matos, A.M.; Nunes, S.; Coutinho, J.S. Cork waste in cement based materials. Mater. Des. 2015, 85, $230-239$. [CrossRef]

5. Carriço, C.; Ribeiro, H.M.; Marto, J. Converting cork by-products to eco-friendly cork bioactive ingredients: Novel pharmaceutical and cosmetics applications. Ind. Crops Prod. 2018, 125, 72-84. [CrossRef]

6. Silva, S.P.; Sabino, M.A.; Fernandes, E.M.; Correlo, V.M.; Boesel, L.F.; Reis, R.L. Cork: Properties, capabilities and applications. Int. Mater. Rev. 2005, 50, 345-365. [CrossRef]

7. Reis, S.F.; Lopes, P.; Roseira, I.; Cabral, M.; Mateus, N.; Freitas, V. Recovery of added value compounds from cork industry by-products. Ind. Crops Prod. 2019, 140, 111599. [CrossRef]

8. Conde, E.; Cadahía, E.; García-Vallejo, M.C.; de Simón, B.F.; Adrados, J.R.G. Low Molecular Weight Polyphenols in Cork of Quercus suber. J. Agric. Food Chem. 1997, 45, 2695-2700. [CrossRef]

9. Sen, A.; Miranda, I.; Santos, S.; Graça, J.; Pereira, H. The chemical composition of cork and phloem in the rhytidome of Quercus cerris bark. Ind. Crops Prod. 2010, 31, 417-422. [CrossRef]

10. Santos, S.A.O.; Pinto, P.C.R.O.; Silvestre, A.J.D.; Neto, C.P. Chemical composition and antioxidant activity of phenolic extracts of cork from Quercus suber L. Ind. Crops Prod. 2010, 31, 521-526. [CrossRef]

11. Bouras, M.; Chadni, M.; Barba, F.J.; Grimi, N.; Bals, O.; Vorobiev, E. Optimization of microwave-assisted extraction of polyphenols from Quercus bark. Ind. Crops Prod. 2015, 77, 590-601. [CrossRef]

12. Batista, M.; Rosete, M.; Ferreira, I.; Ferreira, J.; Duarte, C.; Matias, A.; Poejo, J.; Crespo, J.; Valério, R. Cork Hydroglycolic Extract, Method for Preparing Same, Formulations Comprising Said Extract and Use Thereof. Patent WO2015/152746, 8 October 2015.

13. Galbe, M.; Wallberg, O. Pretreatment for biorefineries: A review of common methods for efficient utilisation of lignocellulosic materials. Biotechnol. Biofuels 2019, 12, 294. [CrossRef]

14. Brunner, G. Near Critical and Supercritical Water, Part I: Hydrolytic and Hydrothermal Processes. J. Supercrit. Fluids 2009, 47, 373-381. [CrossRef]

15. Pereira, H. Chemical composition and variability of cork. Wood Sci. Technol. 1988, 22, 211-218. [CrossRef]

16. Jové, P.; Olivella, M.A.; Cano, L. Study of the variability in chemical composition of bark layers of Quercus suber L. from different production areas. BioResources 2011, 6, 1806-1815.

17. Conde, E.; Cadahia, E.; Garcia-Vallejo, M.C.; Gonzhlez-Adrados, J.R. Chemical characterization of reproduction cork from Spanish Quercus suber. J. Wood Chem. Technol. 1998, 18, 447-469. [CrossRef]

18. Santos, S.A.O.; Villaverde, J.J.; Sousa, A.F.; Neto, C.P.; Silvestre, A.J.D.; Coelho, J.J.F. Phenolic composition and antioxidant activity of industrial cork by-products. Ind. Crops Prod. 2013, 47, 262-269. [CrossRef]

19. Pedras, B.; Salema-Oom, M.; Sá-Nogueira, I.; Simões, P.; Paiva, A.; Barreiros, S. Valorization of white wine grape pomace through application of subcritical water: Analysis of extraction, hydrolysis and biological activity of the extracts obtained. J. Supercrit. Fluids 2017, 128, 138-144. [CrossRef]

20. Templeton, D.W.; Quinn, M.; Wychen, S.V.; Hyman, D.; Laurens, L.M.L. Separation and quantification of microalgal carbohydrates. J. Chromatogr. A 2012, 1270, 225-234. [CrossRef]

21. Cetinkol, O.P.; Smith-Moritz, A.; Cheng, G.; Lao, L.; George, A.; Hong, K.; Henry, R.; Simons, B.A.; Heazlewood, J.L.; Holmes, B.M. Structural and Chemical Characterization of Hardwood from Tree Species with Applications as Bioenergy Feedstocks. PLoS ONE 2012, 7, e52820. [CrossRef]

22. Bandura, A.V.; Lvov, S.N. The Ionization Constant of Water over Wide Ranges of Temperature and Density. J. Phys. Chem. Ref. Data 2006, 35, 15-30. [CrossRef]

23. Möller, M.; Nilges, P.; Harnisch, F.; Schröder, U. Subcritical Water as Reaction Environment: Fundamentals of Hydrothermal Biomass Transformation. ChemSusChem 2011, 4, 566-579. [CrossRef]

24. Uematsu, M.; Franck, E.U. Static Dielectric Constant of Water and Steam. J. Phys. Chem. Ref. Data 1980, 9, 1291-1306. [CrossRef] 
25. Alfei, S.; Turrini, F.; Catena, S.; Zunin, P.; Parodi, B.; Zuccari, G.; Pittaluga, A.M.; Boggia, R. Preparation of ellagic acid micro and nano formulations with amazingly increased water solubility by its entrapment in pectin or non-PAMAM dendrimers suitable for clinical applications. New J. Chem. 2019, 43, 2438-2448. [CrossRef]

26. Mislata, A.M.; Puxeu, M.; Ferrer-Gallego, R. Aromatic Potential and Bioactivity of Cork Stoppers and Cork By-Products. Foods 2020, 9, 133. [CrossRef] [PubMed]

27. Pedras, B.; Nascimento, M.; Sá-Nogueira, I.; Simões, P.; Paiva, A.; Barreiros, S. Semi-continuous extraction/hydrolysis of spent coffee grounds with subcritical water. J. Ind. Eng. Chem. 2019, 72, 453-456. [CrossRef]

28. Aroso, I.M.; Araujo, A.R.; Fernandes, J.P.; Santos, T.; Batista, M.T.; Pires, R.A.; Mano, J.F.; Reis, R.L. Hydroalcoholic extracts from the bark of Quercus suber L. (Cork): Optimization of extraction conditions, chemical composition and antioxidant potential. Wood Sci. Technol. 2017, 51, 855-872. [CrossRef]

29. Cordeiro, N.; Belgacem, M.N.; Silvestre, A.J.D.; Neto, C.P.; Gandini, A. Cork suberin as a new source of chemicals. 1. Isolation and chemical characterization of its composition. Int. J. Biol. Macromol. 1998, 22, 71-80. [CrossRef]

30. Laboratory Analytical Procedure (LAP); Hames, B.; Scarlata, C.; Sluiter, A. Determination of Protein Content in Biomass; National Renewable Energy Laboratory (NREL): Golden, CO, USA, 2008.

31. Järvinen, R.; Silvestre, A.J.D.; Holopainen, H.; Kaimainen, M.; Nyyssölä, A.; Gil, A.M.; Neto, C.P.; Lehtinen, P.; Buchert, J.; Kallio, H. Suberin of Potato (Solanum tubersoum Var. Nikola): Comparison of the Effect of Cutinase CcCut1 with Chemical Depolymerization. J. Agric. Food. Chem. 2009, 57, 9016-9027. [CrossRef] [PubMed]

32. Laboratory Analytical Procedure (LAP); Sluiter, A.; Hames, B.; Ruiz, R.; Scarlate., C.; Sluiter, J.; Templeton, D.; Crocker, D. Determination of Structural Carbohydrates and Lignin in Biomass; National Renewable Energy Laboratory (NREL): Golden, CO, USA, 2012.

33. Yilmaz, F.M.; Karaaslan, M.; Vardin, H. Optimization of extraction parameters on the isolation of phenolic compounds from sour cherry (Prunus cerasus L.) pomace. J. Food Sci. Technol. 2015, 52, 2851-2859. [CrossRef] [PubMed]

34. Sivaraman, T.; Kumar, T.K.S.; Jayaraman, G.; Yu, C. The Mechanism of 2,2,2-Trichloroacetic Acid-Induced Protein Precipitation. J. Protein Chem. 1997, 16, 291-297. [CrossRef]

35. Fernandes, A.; Sousa, A.; Mateus, N.; Cabral, M.; de Freitas, V. Analysis of phenolic compounds in cork from Quercus suber L. by HPLC-DAD/ESI-MS. Food Chem. 2011, 125, 1398-1405. [CrossRef]

36. Dionex Corporation. Product Manual for Dionex CarboPac MA1, PA1, PA10 and PA100 Columns. Available online: http://www.Dionex.com/liu.umd.edu/files/4375-man-031824-08-CarboPac-Combined-May10.pdf (accessed on 10 June 2020).

37. Brás, T.; Guerreiro, O.; Duarte, M.F.; Neves, L.A. Impact of extraction parameters and concentration by nanofiltration on the recovery of phenolic compounds from Cynara cardunculus var. altilis: Assessment of antioxidant activity. Ind. Crops Prod. 2015, 67, 137-142. [CrossRef]

Sample Availability: Samples of the extracts are available from the authors.

Publisher's Note: MDPI stays neutral with regard to jurisdictional claims in published maps and institutional affiliations.

(C) 2020 by the authors. Licensee MDPI, Basel, Switzerland. This article is an open access article distributed under the terms and conditions of the Creative Commons Attribution (CC BY) license (http://creativecommons.org/licenses/by/4.0/). 